\title{
Soil Remediation Applications of Nanotechnology
}

\author{
Risky Ayu Kristanti ${ }^{*}$, Rachael Mei Yen Liong ${ }^{2}$, Tony Hadibarata ${ }^{2}$ \\ ${ }^{1}$ Research Center for Oceanography, Indonesian Institute of Sciences, Pasir Putih I, Jakarta, Indonesia. \\ 2 Department of Environmental Engineering, Faculty of Engineering and Science, Curtin University Malaysia, CDT 250, Miri, \\ Malaysia. \\ * Correspondence: risky.ayu.kristanti@lipi.go.id
}

SUBMITTED: 20 May 2021; REVISED: 19 June 2021; ACCEPTED: 21 June 2021

\begin{abstract}
With the growth of urbanization, the anthropogenic activities have increased and thus increase occurrence of soil contaminants. In order to eliminate the contaminants in soil environment, the application of nanotechnology for soil remediation has become a great concern in the world. This review discussed about the fate of contaminants in soil environment; the mechanisms of nanotechnology with various types of nanomaterials for the soil remediation; the advantages and disadvantage of nanomaterials towards the terrestrial organisms, human health as well as the soil environment; and the challenges of using nanotechnology for soil remediation. The major challenges of nanotechnology are the negative effect of the nanoparticles towards the microbes. The toxicity in nanomaterials will affect the microorganisms and inhibit the enzymes activities in the soil environment.
\end{abstract}

Keywords: Soil remediation; mechanisms of nanotechnology, immobilization, nanomaterials

\section{Introduction}

Soil is one of the importance parts of environment which provides a critical ecosystem benefit for life. However, due to the urbanization, the rapid growth of industrializations has created side effects towards the soil. In recent decades, soil has been contaminated by the hazardous and toxic pollutants that produced from the anthropogenic sources such as disposal of chemical wastes from industrial, abandoned use of fertilizers and pesticides, and other potential chemical sources which lead to the contamination of soil. For instance, 187 million tonnes of fertilizer and 4 million tonnes of pesticides have been used annually for agricultural crop in globally, which has led to the sources of soil contamination [1]. In Europe, the contaminated areas were investigated to be more than 0.5 million areas and approximately 3.5 million of sites were found to be seriously contaminated [2]. There are several soil contaminants which include heavy metals, pesticides, mineral oil and solvents. Heavy metal was found to be the dominant source of soil contaminants, which was also the main concern in many studies, due to the various sources of heavy metals, non-biodegradability and its cumulative behavior [3]. An overview of soil pollutants which conducted in Europe has been reported as presented in Figure 1 , where the heavy metal was accounted for $35 \%$ of total pollutants found in soil [4]. The attention towards the contaminated soil problems has been raised with great concern as the 
contaminated soil will poses potential health impacts to the human, ecosystem, agricultural as well as the environment.

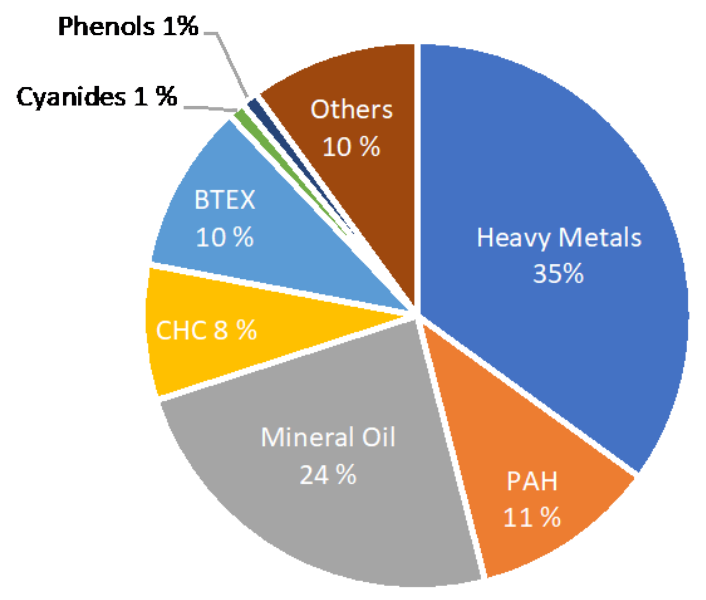

Figure 1. Proportion of soil contaminants in Europe

Nanotechnology and nanomaterials have been widely attracted the attentions from the industrial sector, and was recently being used frequently in several fields such as agricultural, energy and environmental science [5]. Small particle size of 1 to 100 nanometers was being used in the nanotechnology, with different types, high specific surface area, high reactivity and flexibility. Various types of nanomaterials are presented in Figure 2. With the vary properties of nanomaterials, nanomaterials have the potential in removing the contaminants from soil, water and air. The high specific surface area of nanomaterials significantly increases the efficiency in decontamination process. The nanometers size of the nanoparticles enhanced their effectiveness in transported into the contaminated soil. The application of nanotechnology techniques in remediation were investigated to have high efficiency, inexpensive, high flexibility and environmentally friendly [6-7].

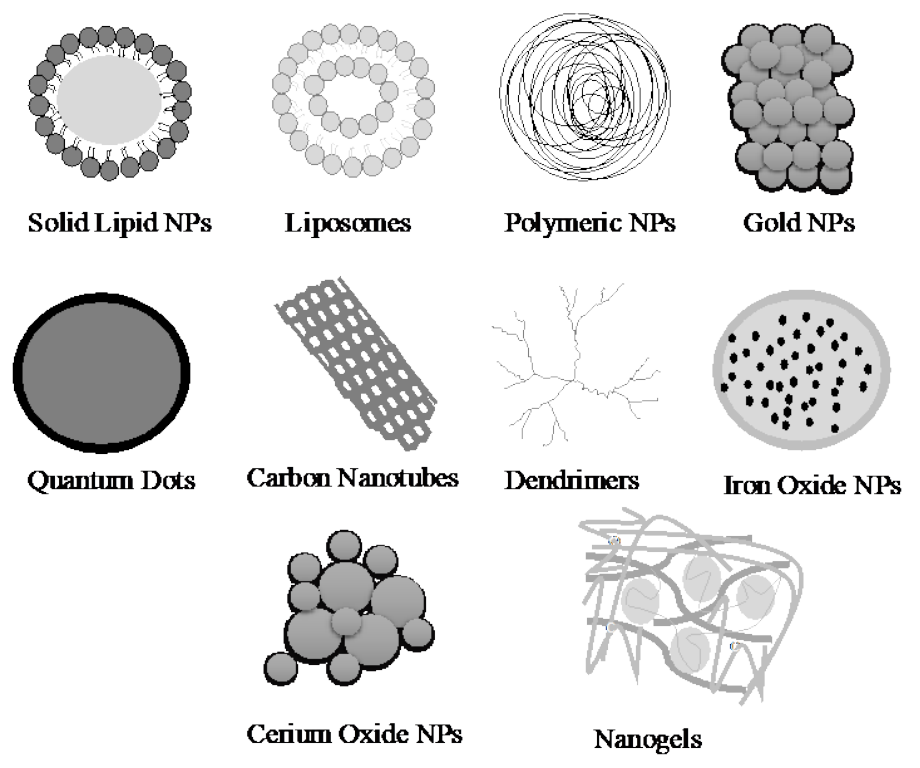

Figure 2. Types of nanomaterials 
The implementation of nanotechnology not only applied in decontamination process but also used to detect the various types of pollutants due to the properties of nanomaterials. Heavy metals such as Lead, Chromium, Copper, Cadmium, Mercury, etc can be removed from soil through the applications of nanotechnology. In this review, the fate of heavy metals, the types of removal mechanism technology as well as the benefit, negative impacts and challenges of nanotechnology will be discussed.

\section{Fate of Soil Contaminants}

The contaminants in soil can be derived in solid, liquid and gaseous phases. There are several factors that causes the contaminants to transport into the soil which include soil properties such as $\mathrm{pH}$, clay content and organic matter content as well as chemical compounds properties. The contaminants in soil are mainly produced through diffuse pollution and point source pollution [8-9]. Diffuse sources of contaminants are typically related to the occurrence of natural phenomena against the agricultural activities and discharge of pollutants from wastewater treatment plant, which will lead to the sedimentation of pollutants in soil through surface water [10]. Point sources are the activities that will produced and transferred the pollutants into the soil such as manufacturers, landfills, industrial activities [10]. The principle of volatilization, leaching and suspension are the dominant mechanisms in transporting the pollutants into the soil [10]. The pollutants that being discharged will transported through the soil and entered the pore space in the soil as well as retained on the surface of mineral or organic matters. The pollutants will also penetrate into wet soil or volatilized into the atmosphere. The most toxicity contaminants in soil are heavy metals, which include the persistent organic pollutants and inorganic pollutants as these pollutants were very resistance to degradation and cannot be destroy or degrade easily. The presence of heavy metal pollutants in soil was mainly due to the anthropogenic activities and the foundation of soil.

Soil is considered as an ultimate sink for various pollutants, especially heavy metals which can persist in soil for few decades. When the contaminants were transported into the soil system, the contaminants will transform into more steady solid phases and retained in organic phase of the soil. The process of this transportation is known as aging and it is a permanent process. The process of aging showed a degradation on soil properties as the formation of aging will reduce the permeability of soil [11]. The contaminants in soil will be sequestered due to the aging process, and the combination of diffusion and adsorption between contaminants and soil will be limited. The factors that cause the occurrence of aging are mainly depends on the quantity and behavior of soil organic matter and black carbon, inorganic components of soil and the structure of soil [11]. The sedimentation of heavy metals in the soil is highly linked to the $\mathrm{pH}$ value of the soil, the presence of clay mineral, content of organic matter and other possible factors.

The value of $\mathrm{pH}$ in soil is the key parameter that effect the mobility and concentration of heavy metals in the soil solution which regulate the occurrence of precipitation dissolution in soil environment. The availability and solubility of heavy metals tend to be decreased with the increase of $\mathrm{pH}$ value in the soil [12]. However, the mobility of heavy metals and toxicity towards the organisms on the soil such as the crops are excepted to be increased. In acidic conditions, the concentration of heavy metal ions in the soil was increased with the precipitation of solid phases of soil [13]. Not only that, the $\mathrm{pH}$ values also governed the formation of specific adsorption, ion exchange, desorption reactions in the surface of soil, and 
the solubility of mineral [14]. The sorption of heavy metal ions was generally proportional to the $\mathrm{pH}$ value of the soil due to the relationship between the $\mathrm{H}^{+}$and $\mathrm{Al}^{3+}$ ions reaction in the adsorption sites. At high $\mathrm{pH}$ values condition, the adsorption of the metal ions was resulted in a hydrolysis complexes of metal compound, which the formation of metal hydroxo complexes was vary from different types of heavy metals against specific $\mathrm{pH}$ values [15]. The concentration of metal ions in the soil environment were significantly reduced due to the $\mathrm{pH}$ level in the soil reaches a limitation towards the metal ions. For instance, the adsorption of ionic organic contaminants showed a significant decrease with the increasing of $\mathrm{pH}$ values from 2 to 3, while remained stable at $\mathrm{pH}$ level of 3 to 6 , and decreased again with the increasing of $\mathrm{pH}$ level. Thus, the threshold levels of $\mathrm{pH}$ for the ionic organic contaminants were within 3 to 6 [16]. On the other hand, the sorption process of the metal ions was reduced at a low $\mathrm{pH}$ level due to the properties of the sorption locations and the acidity of the oxide catalyzes [16]. While the complexation of metal ions with the organic matter was decreasing linearly proportional to the $\mathrm{pH}$ level.

The clay mineral is one of the factors that affecting the transportation of heavy metal pollutants into the soil environment. The specific adsorption as well as the exchange of ions are related to the clay minerals, where the clay minerals has the ability to absorb the metal ions in the soil [8]. The adsorption of metal ions through clay minerals was completed through the adsorption of hydroxyl ions from metal ions or directly removal the proton in the metal ions at the clay mineral's locations. Clay mineral such as kaolinite has a higher ability in retaining heavy metals than other types of clay minerals as different clay minerals has their individual sorption ability at the mineral edges [17]. For kaolinite mineral, the surface edges have greater amount of weakly acidic which enhance the capacity of kaolinite adsorbed the heavy metals to its surfaces. Moreover, the clay minerals such as vermiculite which was able be expand has greater adsorption capacity than kaolinite. This is due to the adsorption process involved the inter-layer spaces of the vermiculite mineral. The clay mineral has higher adsorption capacity compared to silty soil [18]. The organic matter content in soil can also be the factor in affecting the heavy metals content in soil by increasing or decreasing the amount of organic matter content. For instance, the soil with high organic matter content has the capacity in decreasing the presence of metal in the soil and plants through the forming of metal-organic complexes [14]. While the low organic matter content will reduce the adsorption of heavy metals in soil and remains the heavy metals in the form of ions [19]. However, the organic matter content has large impact on the mobility of heavy metals as the heavy metal pollutants were typically attached to the humid compounds in soil [13]. The formation of complexes in organic matter will increase the amount of heavy metals in soil solutions. Besides that, the functional group in metal ions will also affect the adsorption capacity in organic matter [8]. The heavy metals with negatively-charged functional group are more likely to be adsorbed by organic matter and become more stable at high level of $\mathrm{pH}[8]$.

\section{Mechanisms of Nanotechnology}

The application of in situ technique is widely used in soil remediation. The technologies used for remediation of contaminants in soil are mainly adsorption, immobilization, Fenton and Fenton-like oxidation, reduction reaction and multiple combination of nanotechnology and bioremediation. The mechanism of combination of nanotechnology and bioremediation has arisen a great concern in recently [20]. Table 1 below has presented a summary of 
nanomaterials and nanotechnology applied for in situ removal of contaminants from soils, where the contaminants include heavy metals, organic compound and metalloids. The inorganic contaminants such as heavy metals and metalloid were typically removed through the adsorption process by nanoparticles, while the organic contaminants were removed through reduction reaction and degradation with the presence of catalyzes. With the implementation of nanomaterials, the process of adsorption and oxidation were able to degrade as well as remove the micro-pollutants that retained in soil environment. The applications of nanotechnology in soil remediation that are widely used in removing the contaminants include the carbon nanomaterials, Iron (III) oxide $\left(\mathrm{Fe}_{3} \mathrm{O}_{4}\right)$, Titanium oxide $\left(\mathrm{TiO}_{2}\right)$, Zinc oxide $(\mathrm{ZnO})$, nanoscale zero-valent iron (nZVI) and nanocomposites. Among the nanomaterials, nZVI was the most common used of nanoparticles in removing the heavy metal pollutants due to the high efficiency of nZVI in eliminating the contaminants such as toxic metals, chlorinated organic compounds and inorganic compound into less harmful compounds [21].

\subsection{Reduction Reaction}

Reduction reaction has high potential in removing the heavy metals and organic compounds in contaminated soil with the application of nZVI nanoparticles, as well as both the water and groundwater contamination [5]. nZVI particles has been widely applied in wide field scale. Due to the nanoparticle size of nZVI and large surface area, nZVI particles were the capacity to improve the efficiency of remediation by direct contact with contaminants. nZVI particles were being applied into the contaminated soil through injection wall as shown in Figure 3. nZVI particles has a strong reduction capacity and good adsorption ability which are able to convert toxic contaminants to less toxic compound, such as Chromium(VI) converted to Chromium(III) and form a new compound such as ferrous chromite [4]. Moreover, the addition of biochar into the nanoparticles of ZVI was found to enhance the reduction reaction capacity of nZVI and increase the removal efficiency of nZVI in eliminating Chromium(VI) through reinforcement the disparity of iron particles and reduce the movement of mixture in the soil [5]. For example, the combination of biochar and nZVI has removed $66 \%$ of Chromium(VI) content in the soil [5]. It was investigated that a mass of $28 \%$ of $1 \mathrm{~kg}$ Chromium(VI) was reduced with $1 \mathrm{~g}$ of $\mathrm{nZVI}$ injection into the contaminated soil. In addition, $98 \%$ of Chromium (VI) was removed within 24 hours in a treatment condition with $\mathrm{pH}$ level at 5 [33].

Furthermore, the combination of carboxymethyl cellulose stabilizer with nZVI was reported to have high capacity in converting most of the Chromium (VI) contaminants into carbonate-bound as well as Iron-Manganese oxides-bound, where the bioavailability and leachability of Chromium will be by $50 \%$ at a condition of $1 \mathrm{~g}$ to $10 \mathrm{~mL}$ of soil to solution [26]. The combination of carboxymethyl cellulose stabilizer and nZVI was also reported to have great efficiency in removing the organic contaminants such as DDT, TCE and pesticides from soil column. For instance, $44 \%$ of TCE was dechlorinated within 30-hours treatment period through the injection of CMC-stabilized nZVI into the potting soil with $9.2 \%$ of organic matter in soil [22]. With the injection of $20 \%$ aqueous nZVI $1 \mathrm{~kg}$ of soil, $25 \%$ of DDT was removed in $1 \mathrm{~kg}$ of soil which containing $24 \mathrm{mg}$ of DDT per kg soil within 72-hours. In order to enhance the reaction activity of nZVI, higher amount of nZVI was needed to remediate the soils that contaminated for long period of time [22]. 


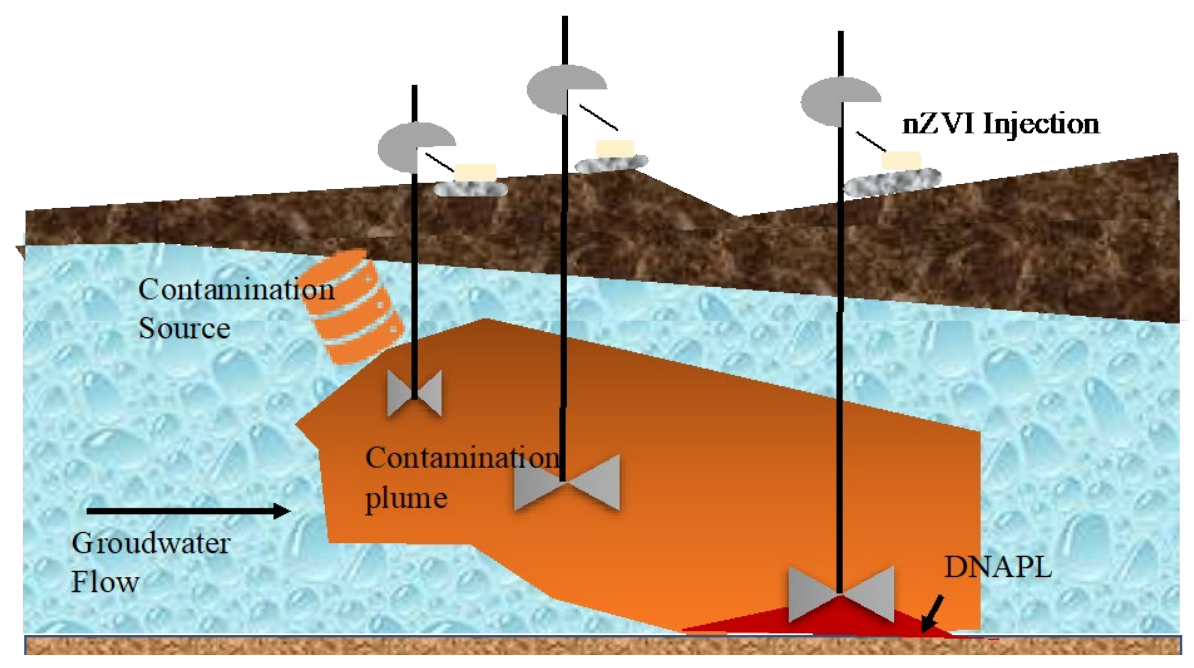

Figure 3. Injection of nZVI for in situ soil remediation

\subsection{Immobilization}

The mechanism of in situ immobilization of contaminants has received great attention in worldwide as immobilization is a cost-effective and environmental friendly technique for remediation of contaminated soil [1]. For immobilization remediation, the nanomaterials selected were highly depending on the properties of the contaminants and the condition of soils. Several nanoparticles additives have been selected and widely applied in the immobilization remediation of organic and inorganic pollutants in the soil environment [5]. These nanoparticles additive selected include the carbon nanomaterials and metal oxide nanomaterials. For carbon nanomaterials, the organic contaminants were being absorb through van der Waals forces and interactions between $\pi-\pi$. Carbon nanomaterials can be classified into various structural configurations such as fullerene, carbon nanotubes and graphene which act as an adsorbent in immobilization remediation. The characteristics of hydrophobicity surface and high adsorption ability of carbon nanomaterials enhance the potential of carbon nanomaterials in removing the organic contaminants in soils [34]. The application of carbon nanotubes was being considered due to the high adsorption properties of carbon nanotubes to the organic compounds compared to the organic matter in soils [7]. Furthermore, carbon nanotubes were found to have specific adsorption towards the ionizable organic compound such as pesticides through the interaction between $\pi$ - $\pi$ and cation- $\pi$. Not only that, carbon nanotubes have low-barrier surface and hydrogen bond with electron charged [7]. The application of carbon nanotubes has been widely investigated in various condition in order to reduce the organic compounds such as PAHs [5]. For instance, the presence of carbon nanotubes in soil could hinder the movement of PAHs and reduce the bioavailability of PAHs towards the crops and microorganisms in soil environment [34]. Moreover, the oxygen content can influence the adsorption capacity of carbon nanotubes. The functional group of - $\mathrm{OH}$ can increase the adsorption capacity of carbon nanotubes by strengthen the interaction between $\pi$ $\pi$ and $-\mathrm{OH}[34]$. 
Table 1. A summary of various mechanism of nanotechnology applications for in situ soil remediation.

\begin{tabular}{|c|c|c|c|c|c|c|}
\hline Mechanism & $\begin{array}{c}\text { Nano- } \\
\text { materials }\end{array}$ & Pollutants & $\begin{array}{l}\text { Pollutants } \\
\text { Conc. }\end{array}$ & $\begin{array}{c}\text { Nano- } \\
\text { materials Conc. }\end{array}$ & Results & References \\
\hline \multirow[t]{7}{*}{$\begin{array}{l}\text { Reduction } \\
\text { reaction }\end{array}$} & nZVI & $\begin{array}{l}\text { Dichloro- diphenyl- trichloroethane } \\
\text { (DDT) }\end{array}$ & $24 \mathrm{mg} / \mathrm{kg}$ & $20 \%$ aqueous & $25 \%$ of DDT removal within 3 days & {$[22]$} \\
\hline & nZVI & $\begin{array}{l}\text { Dichloro- diphenyl- trichloroethane } \\
\text { (DDT) }\end{array}$ & $0.15 \mathrm{~g}$ & $5 \mathrm{wt} \%$ & $2.5 \%$ of DDT removal per nZVI & {$[23]$} \\
\hline & $\mathrm{nZVI}$ & Chromium (VI) & $50 \mathrm{mg} / \mathrm{L}$ & $45.7 \mathrm{~m}^{2} / \mathrm{g}$ & $62 \%$ removal within $60 \mathrm{~min}$ & {$[23]$} \\
\hline & $\begin{array}{l}\text { nZVI activated } \\
\text { persulfate }\end{array}$ & $\begin{array}{l}\text { polycyclic aromatic hydrocarbons } \\
\text { (PAHs) }\end{array}$ & $17 \mu \mathrm{g} / \mathrm{g}$ & $\begin{array}{c}3 \mathrm{wt} \% \text { of } \\
\text { persulfate } \& 0.35 \\
\text { wt } \% \text { of nZVI }\end{array}$ & $82.2 \%$ removal within 104 days & [24] \\
\hline & $\begin{array}{c}\mathrm{CMC} / \mathrm{HA} \\
@ \mathrm{nZVI}\end{array}$ & Chromium (VI) & $110 \mu \mathrm{g} / \mathrm{g}$ & $3 \mathrm{wt} \%$ & $74.5 \%$ reduction within 3 months & {$[25]$} \\
\hline & CMC-nZVI & Chromium (VI) & $800 \mu \mathrm{g} / \mathrm{g}$ & $1.1 \mathrm{wt} \%$ & $95 \%$ reduction within a week & {$[26]$} \\
\hline & PVP-nZVI & $\begin{array}{c}\text { Tri-chloroethylene } \\
\text { (TCE) }\end{array}$ & $727 \mu \mathrm{g} / \mathrm{kg}$ & $0.4 \mathrm{~g}$ & $84.73 \%$ dechlorination of TCE & {$[27]$} \\
\hline \multirow[t]{5}{*}{ Immobilization } & $\begin{array}{l}\text { Carbon nanotubes } \\
\text { (CNTs) }\end{array}$ & $\begin{array}{c}\text { polycyclic aromatic hydrocarbons } \\
\text { (PAHs) }\end{array}$ & $4000 \mu \mathrm{g} / \mathrm{L}$ & $0.25 \mathrm{wt} \%$ & $66.1 \%$ removal within 24 hours & [7] \\
\hline & $\begin{array}{c}\text { nanosized } \\
\text { hydroxyapatite } \\
\text { nHAP }\end{array}$ & Copper $(\mathrm{Cu})$ & $547 \mu \mathrm{g} / \mathrm{g}$ & $5 \mathrm{wt} \%$ & Fully removal of $\mathrm{Cu}$ & {$[29]$} \\
\hline & nHAP & Zinc $(\mathrm{Zn})$ & $70.4 \mu \mathrm{g} / \mathrm{g}$ & $5 \mathrm{wt} \%$ & Completely reduction of $\mathrm{Zn}$ & [29] \\
\hline & nZVI & As & $70.2 \mathrm{mg} / \mathrm{g}$ & $5 \mathrm{wt} \%$ & $70 \%$ removal of As & {$[30]$} \\
\hline & $\begin{array}{l}\text { Titanium dioxide } \\
\mathrm{TiO}_{2}\end{array}$ & $\begin{array}{l}\text { diphenylarsinic acid } \\
\text { (DPAA) }\end{array}$ & $20 \mu \mathrm{g} / \mathrm{g}$ & $5 \mathrm{wt} \%$ & $82 \%$ removal within 3 hours & {$[31]$} \\
\hline $\begin{array}{l}\text { Fenton-like } \\
\text { oxidation }\end{array}$ & $\mathrm{Fe}_{3} \mathrm{O}_{4}$ & PAHs & $100 \mu \mathrm{g} / \mathrm{g}$ & $18 \mathrm{mM}$ & $85.2 \%$ of removal at $\mathrm{pH} 3.5$ & {$[32]$} \\
\hline
\end{tabular}


For metal oxide nanomaterials, the contaminants were removed through surface complexation. Metal oxides such as Iron(III) oxide and Titanium dioxide are commonly being applied in soil remediation. Due to the high adsorption capacity of Iron(III) oxide, it can remove heavy metals such as Arsenic and Cadmium. For instance, Iron(III) oxide has a maximum of $37.03 \mathrm{mg} / \mathrm{g}$ of adsorption capacity in remediated the Cadmium under a condition with $\mathrm{pH}$ level of 6.0 [5]. Besides that, the maximum adsorption capacity for Titanium dioxide was found to have $94 \%$ of sorption rate in removing the Th(IV) under a condition of $\mathrm{pH} 4.0$. The acidic condition of soil enhanced the sorption process by promoting the surface complexation to become the main adsorption mechanism [35].

\section{Pros and Cons of Nanotechnology}

With the increasing of the application of nanotechnology in soil remediation, the amount of nanomaterials will also be increased and entered the environment. The high amount of nanomaterials may produce unpredicted risk towards the soil environment and ecosystem and indirectly threaten to human health. The main concern is the transportation of nanomaterials in the soil environment may transmitted into the groundwater system and pollute the water resources as well as the drinking water system and bring adverse impacts towards the terrestrial organisms and human health [34]. The application of nanotechnology brings both benefits and disadvantages towards the ecosystem and environment.

The presence of nanomaterials in the soil environment could enhance the growth of seeds and plants due to the enrichment of useful nutrients and pesticides [5]. For instance, the various nanomaterials such as carbon nanotubes, metal and metal oxide nanomaterials has the ability to enhance the nutrient in soil by delivering the nutrient to the roots and leaves of the crops and thus improve the growth of crops [1]. The application of metal oxide nanomaterials such as $\mathrm{CuO}$ has the potential to enhance the crops yield as well as the growth of crops due to the presence of virulent pathogens in $\mathrm{CuO}$ nanomaterial [5].

The disadvantage of the application of nanotechnology is the potential of toxicity towards the terrestrial organisms and soil ecosystem. It was found that there is potential toxic from nanomaterials towards the plant's cells. For instance, the concentration of carbon nanomaterials such as fullerene was found to be high in the plant's cells due to the process of translocation as well as uptake process [26]. The translocation of the hydrophobic nanomaterials was due to the natural phenomena in the xylem, where the transport of nanomaterials was through the uptake of water and nutrients. Through the life cycle system, the uptake of toxic by the plants will indirectly impacts towards the human through the ingestion of toxic crops. Besides that, the nanomaterials will also impact towards the properties of soils due to the small size of nanomaterials and high specific surface area. The nanomaterials could increase the porosity of soil and enhance the interaction between soil particles and organic matter [14].

\section{Challenges of Nanotechnology}

The major challenges of nanotechnology are the negative effect of the nanoparticles towards the microbes. The toxicity in nanomaterials will affect the microorganisms and inhibit the enzymes activities in the soil environment. Several studies have been done to reduce and prevent the toxicity of nanomaterials towards the soil organisms. However, various conflict 
results have been reported as some studies presented the inhibitory ability and some studies investigated the biostimulation impacts towards the microbial in soil system $[1,5,20]$. In order to overcome the negative impacts that cause by the application of nanotechnology, further research and experiment are required to be investigated.

\section{Conclusions}

In summary, the application of technology for soil remediation includes the mechanism of reduction reaction and immobilization. Carbon nanomaterials, nZVI and metal oxide nanomaterials are the most efficient in removing or reducing the contaminants in the soils. The fate of contaminants in the soil environment is mainly linked to the $\mathrm{pH}$ value of the soil, the presence of clay mineral and content of organic matter. The application of nanotechnology has high efficiency in remediated the contaminated soils as well as enhance the useful nutrient to the plants and crops and increase the growth of yield. However, the nanomaterials could bring toxicity towards the plants cells and have negative impacts towards the soil environment as well as threaten human health. Thus, the application of nanotechnology in soil remediation is still require for further more investigation in order to promote the global environment.

\section{Acknowledgments}

The authors thank Indonesia Institute of Sciences and Curtin University Malaysia for facilitating this work.

\section{Competing Interest}

The authors declare that they have no conflict of interest

\section{References}

[1] Usman, M; Farooq, M; Wakeel, A; Nawaz, A; Cheema, S.A; Rehman, H; Ashraf, I; Sanaullah, M. (2020). Nanotechnology in agriculture: Current status, challenges and future opportunities. Science of Total Environment, 721,137778. https://doi.org/10.1016/j.scitotenv.2020.137778.

[2] Majone, M; Verdini, R; Aulenta, F; Rossetti, S; Tandoi, V; Kalogerakis, N; Agathos, S; Puig, S; Zanaroli, G; Fava, F. (2015). In situ groundwater and sediment bioremediation: barriers and perspectives at European contaminated sites. New Biotechnology, 32(1), 133-146. https://doi.org/10.1016/j.nbt.2014.02.011.

[3] Fajardo, C; Sánchez-Fortún, S; Costa, G; Nande, M; Botias, P; García-Cantalejo, J; Mengs, G; Martin, M. (2020). Evaluation of nanoremediation strategy in a $\mathrm{Pb}, \mathrm{Zn}$ and $\mathrm{Cd}$ contaminated soil. Science of The Total Environment, 706, 136041. https://doi.org/10.1016/j.scitotenv.2019.136041.

[4] Rabbani M.M; Ahmed I; Park S.J. (2016) Application of Nanotechnology to Remediate Contaminated Soils. In: Hasegawa H., Rahman I., Rahman M. (eds) Environmental Remediation Technologies for Metal-Contaminated Soils. Springer, Tokyo. pp. 219-229. https://doi.org/10.1007/978-4-431-55759-3_10.

[5] Qian, Y; Qin, C; Chen, M; Lin, S. (2020). Nanotechnology in soil remediation - applications vs. implications. Ecotoxicology and Environmental Safety, 15(201), 110815. doi: 10.1016/j.ecoenv.2020.110815.

[6] Wei, Q; Yang, D; Fan, M; Harris, H.G. (2013). Applications of nanomaterials-based membranes in pollution control. Critical Reviews in Environmental Science and Technology, 43(22), 2389 2438. https://doi.org/10.1080/10643389.2012.672066.

[7] Zhang, T; Lowry, G; Capiro, N.L; Chen, W; Chen, Y; Dionysiou, D.D; Elliott, D; Choshal, S; Hofmann, T; Hsu-Kim, H; Hughes, J; Jiang, C; Jiang, G; Jing, C; Kavanaugh, M; Li, Q; Liu, 
S; Ma, J; Pan, B; Phenrat, T; Qu, X; Quan, X; Saleh, N; Vikesland, P.J; Wang, Q; Westerhoff, P; Wong, M.S; Xia, T; Baoshan, X; Bing, Y; Zhang, L; Zhou, D; Alvarez, P.J.J. (2019). In situ remediation of subsurface contamination: opportunities and challenges for nanotechnology and advances materials. Environmental Science: $\quad$ Nano, $\quad 6(5), \quad 1283 \quad-\quad 1302$. https://doi.org/10.1039/C9EN00143C.

[8] Petruzzelli, G; Gorini, F; Pezzarossa, B; Pedron, F. (2010). The fate of pollutants in soil. In CNR Environment and Health inter-department Project, Bianchi, F; Cori, L; Moretti, P.F., Eds.; Consiglio Nazionale delle Ricerche: Roma, Italy, pp. 1-31. https://www.researchgate.net/publication/326463752_The_fate_of_pollutants_in_soil

[9] Clothier, B; Green, S; Deurer, M; Smith, E; Robinson, B. (2010). Transport fate of contaminatns in soils: challenges and development, Proceedings of $19^{\text {th }}$ World Congress of Soil Science, Soil Solution for a changing world. Brisbane, Australia, 1-6 August 2010, https://www.iuss.org/19th\%20WCSS/Symposium/pdf/0363.pdf

[10] Cachada, A; Rocha-Santos, T; Duarte, A.C. (2018). Chapter 1 - Soil and pollution: an introduction to main issues. Soil Pollution, 1 - 28. In Soil Pollution, Duarte, AC; Cachada, A; Rocha-Santo, T., Eds.;Academic press, pp. 1-28. https://doi.org/10.1016/B978-0-12-8498736.00001-7.

[11] Ltifi, M; Abichou, T; Tisot, J.P. (2014). Effects of soil aging on mechanical and hydraulic properties of a silty soil. Geotechnical and geological engineering, 32, 1101-1108). https://doi.org/10.1007/s10706-014-9784-1.

[12] Buss, W; Shepherd, J.G; Heal, K.V; Masek, O. (2018). Spatial and temporal microscale pH change at the soil-biochar interface. Geoderma, 331, 50 - 52. https://doi.org/10.1016/j.geoderma.2018.06.016.

[13] Reijonen, I; Metzler, M; Hartikainen, H. (2016). Impact of soil $\mathrm{pH}$ and organic matter on the chemical bioavailability of vanadium species: The underlying basis for risk assessment. Environmental Pollution, 210, 371 - 379. https://doi.org/10.1016/j.envpol.2015.12.046.

[14] Bayouli, I.T; Gómez-Gómez, B; Bayouli, H.T; Pérez-Corona, T; Meers, E; Ammar, E; Ferchichi, A; Albarrán, Y.M. (2020). Heavy metal transport and fate in soil-plant system: study case of industrial cement vicinity, Tunisia. Arabian Journal of Geosciences, 13, 75. https://doi.org/10.1007/s12517-019-4898-7.

[15] Khalid, S; Shahid, M; Murtaza, B; Bibi, I; Natasha, Naeem, M.A; Niazi, N.K. (2020). A critical review of different factors governing the fate of pesticides in soil under biochar application. $\begin{array}{lllll}\text { Science of The Total Environment, } & 711,\end{array}$ https://doi.org/10.1016/j.scitotenv.2019.134645.

[16] He, Y; Yao, T; Tan, S; Yu, B; Liu, K; Hu, L; Luo, K; Liu, M; Liu, X; Bai, L. (2019). Effects of $\mathrm{pH}$ and gallic acid on the adsorption of two ionizable organic contaminants to rice straw-derived biochar-amended soils. Ecotoxicology and Environmental Safety, 184, 109656. https://doi.org/10.1016/j.ecoenv.2019.109656.

[17] Diao, Z; Yan, L; Dong, F; Chen, Z; Guo, P; Qian, W; Zhang, W; Liang, J; Huang, S; Chu, W. (2021). Ultrasound-assisted catalytic reduction of $\mathrm{Cr}(\mathrm{VI})$ by an acid mine drainage based nZVI coupling with FeS2 system from aqueous solutions: Performance and mechanism. Journal $\begin{array}{lllll}\text { of Environmental } & \text { Management, } & 278 & \text { (1), } & 1111518 .\end{array}$ https://doi.org/10.1016/j.jenvman.2020.111518.

[18] Dardouri, S; Sghaier, J. (2018). Adsorption characteristics of layered soil as delay barrier of some organic contaminants: Experimental and numerical modeling. Environmental Modelling \& Software, 110, 95 - 106. https://doi.org/10.1016/j.envsoft.2018.09.003.

[19] Tang, X; Li, X; Liu, X; Hashmi, M.Z; Xu, J.; Brookes, P.C. (2015). Effects of inorganic and organic amendments on the uptake of lead and trace elements by Brassica chinensis grown in an acidic red soil. Chemosphere, 119, 117 - 183. doi: 10.1016/j.chemosphere.2014.05.081.

[20] Cecchin, I; Reddy, K.R; Thome, A; Tessaro, E. F; Schnaid, F. (2017). Nanobioremediation: Integration of nanoparticles and bioremediation for sustainable remediation of chlorinated organic contaminants in soil. International Biodeterioration \& Biodegradation, 119, 419-428. https://doi.org/10.1016/j.ibiod.2016.09.027.

[21] Fajardo, C; Ortiz, L.T; Rodríguez-Membibre, M.L; Nande, M; Lobo, M.C; Martin, M. (2012). Assessing the impact of zero-valent iron (ZVI) nanotechnology on soil microbial structure and 
functionality: A molecular approach. Chemosphere, 86(8), 802-808. https://doi.org/10.1016/j.chemosphere.2011.11.041.

[22] El-Temsah, Y.S; Sevcu, A; Bobcikova, K; Cernik, M; Joner, E. J. (2016). DDT degradation efficiency and exotoxicological effects of two types of nano-sized zero-valent iron (nZVI) in water and soil. Chemosphere, 144, 2221-2228. https://doi.org/10.1016/j.chemosphere.2015.10.122.

[23] Blundell, S. P; Owens, G. (2021). Evaluation of enhancement techniques for the dichlorination of DDT by nanoscale zero-valent iron. Chemosphere, 264(1), 123824. https://doi.org/10.1016/j.chemosphere.2020.128324.

[24] Song, Y; Fang, G; Zhu, C; Zhu, F; Wu, S; Chen, N; Wu, T; Wang, Y; Gao, J; Zhou, D. (2019). Zero-valent iron activated persulfate remediation of polycyclic aromatic hydrocarboncontaminated soils: An in situ pilot-scale study. Chemical Engineering Journal, 355, 65 - 75. https://doi.org/10.1016/j.cej.2018.08.126.

[25] Hou, S; Wu, B; Peng, D; Wang, Z; Wang, Y; Xu, H. (2019). Remediation performance and mechanism of hexavalent chromium in alkaline soil using multi-layer loaded nano-zero-valent iron. Environmental Pollution, 252, 553 - 561. https://doi.org/10.1016/j.envpol.2019.05.083.

[26] Zhang, R; Zhang, N; Fang, Z. (2018). In situ remediation of hexavalent chromium contaminated soil by CMC-stabilized nanoscale zero-valent iron composited with biochar. Water Science \& Technology, 77(6), 1622 - 1631. doi: 10.2166/wst.2018.039.

[27] Tian, H; Liang, Y; Yang, D; Sun, Y. (2020). Characteristics of PVP-stabilised NZVI and application to dechlorination of soil-sorbed TCE with ionic surfactant. Chemosphere, 239, 124807. https://doi.org/10.1016/j.chemosphere.2019.124807.

[28] Bidast, S; Golchin, A; Baybordi, A; Zamani, A; Naidu, R. (2020). The effects of non-stabilised and Na-carboxymethylcellulose-stabilised iron oxide nanoparticles on remediation of Co$\begin{array}{llll}\text { contaminated } & \text { soils. } & \text { Chemosphere, } & 261,\end{array}$ https://doi.org/10.1016/j.chemosphere.2020.128123.

[29] Sun, R; Chen, J; Fan, T; Zhou, D; Wang. Y.J. (2018). Effect of nanoparticle hydroxyapatite on the immobilization of $\mathrm{Cu}$ and $\mathrm{Zn}$ in polluted soil. Environmental Science and Pollution Research, 25, 73 - 80. https://doi.org/10.1007/s11356-016-8063-5.

[30] Gil-Díaz, M; Alonso, J; Rodríguez-Valdés, E; Gallego, J R; Lobo, M. C. (2017). Comparing different commercial zero valent iron nanoparticles to immobilize As and $\mathrm{Hg}$ in brownfield soil. Science of The Total Environment, 584, 1324 - 1332. doi: 10.1016/j.scitotenv.2017.02.011.

[31] Wang, A; Teng, Y; Hu, X; Wu, L; Huang, Y; Luo, Y; Christie, P. (2016). Diphenylarsinic acid contaminated soil remediation by titanium dioxide (P25) photocatalysis: Degradation pathway, optimization of operating parameters and effects of soil properties. Science of The Total Environment, 541, 348 - 355. https://doi.org/10.1016/j.scitotenv.2015.09.023.

[32] Barzegar, G; Jorfi, S; Soltani, R.D.C; Ahmadi, M; Saeedi, R. (2017). Enhanced Sono-FentonLike Oxidation of PAH-Contaminated Soil Using Nano-Sized Magnetite as Catalyst: Optimization with Response Surface Methodology. Soil and Sediment Contamination, 26(5), 538-557. https://doi.org/10.1080/15320383.2017.1363157.

[33] Chrysochoou, M; Johnston, C.P; Dahal, G. (2012). A comparative evaluation of hexavalent chromium treatment in contaminated soil by calcium polysulfide and green-tea nanoscale zerovalent iron. Journal of Hazardous Materials, 201, 33-42. doi: 10.1016/j.jhazmat.2011.11.003.

[34] Guerra, F.D; Attia, M.F; Whitehead, D.C; Alexis, F. (2018). Nanotechnology for environmental remediation: materials and applications. Molecules, 23(7), 1760. doi: $10.3390 /$ molecules 23071760 .

[35] Tan, X; Wang, X; Chen, C; Sun, A. (2007). Effect of soil humic and fulvic acids, pH and ionic strength on Th(IV) sorption to TiO2 nanoparticles. Applied Radiation and Isotopes, 65(4), 375381. https://doi.org/10.1016/j.apradiso.2006.10.014.

(C) 2021 by the authors. This article is an open access article distributed under the terms and conditions of the Creative Commons Attribution (CC BY) license (http://creativecommons.org/licenses/by/4.0/). 